\title{
Menuntut Ilmu Pangkal Move On
}

Oleh: Amar Ma'ruf (Penulis Buku Move On)

"Barang siapa merintis jalan mencari ilmu, maka Allah akan memudahkan baginya jalan ke surga." (HR. Muslim)

Manusia lahir dari kandungan dengan tidak mengetahui apapun. Namun dibekali pikiran (aql), hati (qolb), jiwa (nafs), serta indera sehingga mesti berupaya cari ilmu bermanfaat seluasnya. Sesuai pada ayat Q.S An Nahl ayat 78 yang artinya "Allah mengeluarkan kamu dari perut ibumu dalam keadaan tidak mengetahui sesuatupun, dan Dia memberi kamu pendengaran, penglihatan dan hati."

Wahyu pertama yang diturunkan Allah SWT kepada Rasulullah SAW berisi perintah menuntut ilmu. Tanpa ilmu, kita tidak paham melewati hidup dengan benar, baik, dan mulia. Seorang sopir akan kesulitan berkendara di daerah yang belum pernah ia kunjungi jika tidak paham rambu lalu lintas. Sebaliknya, ia akan luwes berkendara apabila paham tiap rambu yang berada di sepanjang jalan. Itulah perumpamaan ilmu.Ilmu adalah rambu bagi manusia untuk menjalani hidup. Ada ilmu bersifat duniawi dan adayang bersifat ukhrowi (akhirat). Keduanya sama penting. Keduanya tidak dapat dipisahkan. Ilmuduniawi harus ditujukan untuk amal akhirat, maka mesti berpegangpada rambu-rambu dari Allah.

Berkaitan dengan rambu, ada rambu yang terlihat dan ada rambu tidak terlihat. Rambu tidak terlihat biasa berasal dari pengalaman yang pernah kita alami. Jika sudah hafal jalan, tanpa ada rambu penunjuk jalan pun kita tidak akan tesasar. Sebab, jalan sudah pernah kita lewati. Persis seperti pengalaman. Pengalaman apa pun, bisa pengalaman baik maupun pengalaman pahit. Jangan bilang pengalaman pahit tidak penting. Justru hati jadi kuat karena kepahitan. Penglaman pahit juga ilmu yang berguna. Kita bisa menjadikannya untuk move on agar tidak jatuh lagi. Sekali pun pahit itu bentuknya kebiasaan jelek. Tapi, seburuk-buruknya kebiasaan akan menjadi kebaikan jika kita sudah berhasil meninggalkannya.

Mengejar ilmu termasuk usaha agarkita terhindar dari kufur. Kufurterjadi jika setiap nikmat dari Allah tidak ditujukan untuk bertaqwa kepada Allah SWT. Penyebabnya pengisi jiwa mengalami masalah, yakni kurang menguasai ilmu tentang 
kehidupan. Pengisi jiwa ada 3, yaitu pikiran, hati, dan jiwa itu sendiri. Ilmu yang sedikit membuat manusia tidak paham rambu penuntun jalan ke surga. Hati yang tertutupi banyak dosa membuat manusia tidak mampumenjadikan apa pun sebagai cara ke surga. Jiwa yang terlalu cinta dunia membuat manusia tidak merasa nikmat ketika berjalan menuju surga. Salah satu cara mengatasinyaialahbelajar terus-menerus agar akal kembali lurus.

Semakin keras untuk belajar, semakin tinggi kualitas diri kita.Begitu banyak ilmu tentang kehidupan terbentang yang harus kita gali, tidak boleh disia-siakan.Ilmu yangmulia mengantar kita untuk mulia,jikaditujukan sebagai tabunganamal, sebagai cara memberi kemanfaatan.Maka, sembari berusaha mengejarnya, mintalah kepada Maha pemberi ilmu agar selalu dilimpahkan ilmu yang bermanfaat.

Sungguh, Islam sebagai agama yang mengajarkan penganutnya supaya cinta pada pengetahuan. Peradaban Islam telah melahirkan para ilmuwan yang sholeh. Para ilmuwan yang melahirkan pengetahuan sebagai kemanfaatan, sebagai usaha melahirkan tatanan hidup lebih mulia. Seperti Al Farabi, di dunia barat dikenal dengan nama Alpharabius. Ia adalah seorang filsuf yang dipandang sebagai salah satu pemikir terkemuka di era abad pertengahan. Atau Tsabit bin Qurro', di dunia barat dikenal dengan nama Thebit. Tsabit dikenal sebagai ahli matematika, kesehatan, dan astronomi. Selanjutnya ada Muhammad Ibn Musa Al Khawarizmi sebagai ahli Al Jabr dan astronomi.

\section{Tahu Banyak, Banyak Tahu}

Kita mesti tahu banyak tentang bidang ilmu yang kita fokuskan. Kita juga mesti tahu terhadap segala hal. Semakin tahu banyak hal, semakin sempurna piramida bidang ilmu yang kita fokuskan. Potensi paling unggulialah pucuk piramida, dan pengetahuan lainnya menjadi puing-puing kokoh di bawahnya. Kita bisa menjadikan Lionel Messi sebagai contoh. Kini, ia menjadi pencetak gol terbanyak di Liga Champions Eropa, bersaing ketat dengan rivalnya, Christiano Ronaldo. Messi tidak akan bisa memecahkan rekor tersebut jika hanya menguasai teknik menendang saja. Ia perlu bisa dribbling, menyundul, oper, dan teknik lainnya.Maka naluri mencetak golnya menjadi komplit.

Setelah menyimak tantang Messi, salah sangka kalau menganggap semakin tahu banyak hal maka semakin sulit untukfokus pada bidang ilmu yang kita pilih. Para ilmuwan yang sudah kita bahas di atas sudah membuktikan. Kebanyakan dari mereka ahli 
dalam beberapa bidang sekaligus. Tidak melulu menyerahkan diri hanya untuk satu urusan. Ada empat perumpamaan tentang hal ini, yakni samudera yang dangkal, sumur yang dalam, samudera dangkal dengan beberapa palung, dan samudera yang dalam. Untuk menjadi samudera yang dalam, sebagian besar dari kita tentu kesulitan. Peluangnya amat kecil untuk menjadi ahli dalam semua bidang. Walaupun harus tetap ada upaya sebaik-baiknya. Paling tidak menjadi samudera dangkal dengan beberapa palung. Artinya, kita punya wawasan luas tentang semua bidang, lalu punya beberapa bidang yang kita tekuni sampai menjadi ahli.

Berusahalah untuk tidak menjadi samudera yang dangkal atau hanya sumur yang dalam. Wawasan itu sangat penting. Wawasan luas menyempurnakanfokus bidang yang kita pilih. Wawasan sebagai pondasi dan puing kokoh dari pucuk piramida. Wawasan luas mampu mengusir awam dan mengusir merasa paling benar, serta mampu menambah koleksi kemanfaatan. Menghadirkan kemanfaatan merupakan hadiah untuk kerinduan jiwa. Karena asal jiwa adalah akhirat. Sementara member kemanfaatan bagi insan lainnya meruapakan nuansa tujuan akhirat.

Allahu a'lam bis showab. 